\title{
Influence of Temperature, Agitation, Sludge Concentration and Solids Retention Time on Primary Sludge Fermentation
}

\author{
J. Sánchez Rubal, J. A. Cortacans Torre, and I. del Castillo González \\ Departamento de Ordenación del Territorio, Urbanismo y Medio Ambiente de la E. T. S. I. de Caminos, Canales y Puertos de la \\ Universidad Politécnica de Madrid, C/ Profesor Aranguren s/n, 28040 Madrid, Spain
}

Correspondence should be addressed to J. Sánchez Rubal, jesus_sanrub@hotmail.com

Received 31 October 2011; Revised 15 February 2012; Accepted 23 February 2012

Academic Editor: Jose C. Merchuk

Copyright (๑) 2012 J. Sánchez Rubal et al. This is an open access article distributed under the Creative Commons Attribution License, which permits unrestricted use, distribution, and reproduction in any medium, provided the original work is properly cited.

\begin{abstract}
The aim of this research was to determine the influence of temperature, agitation, sludge concentration, and solids retention time (SRT) to obtain readily biodegradable organic matter on primary sludge (PS) fermentation, which would be used as substrate in a biological nutrient removal (BNR) process. Stirring and heating the sludge as well as increasing SRT improved the PS fermentation, producing a large amount of soluble chemical oxygen demand (SCOD). The influence of each operational parameter on PS hydrolysis was observed clearly. A great performance on SCOD production was obtained when the PS was stirred and heated for 3 days. However, PS concentration did not affect the fermentation. Sludge agitation is a simple process with minimal energy consumption. Warming the sludge is very interesting in those plants with anaerobic digestion, where heat energy is obtained from biogas. Therefore, PS fermentation can be improved with a minimum investment and leveraging existing resources in a wastewater treatment plant (WWTP). Fermenter volume can also be reduced if sludge is being heated and stirred during fermentation.
\end{abstract}

\section{Introduction}

Optimization of wastewater treatment plants (WWTPs) equipped with BNR processes has been taking place in Spain, in recent years, to satisfy the requirements of phosphorus and nitrogen set by the Council Directive of 21 May 1991 concerning urban waste water treatment (91/271/EEC). These requirements are listed in Table 1.

The fraction of organic matter that is readily biodegradable, namely, the organic matter that could be metabolized directly by heterotrophic bacteria in anoxic and anaerobic zones is a key parameter on BNR processes. However, the influent of the vast majority of the WWTP contains low readily biodegradable organic matter, particularly in urban plants. Therefore, in many cases, it is impossible to achieve a total nitrogen lower than $10 \mathrm{mg} / \mathrm{L}$ in the effluent of WWTP with over 100,000 inhabitants. A supply of readily biodegradable organic matter is required.

The supply of readily biodegradable organic matter can be external to the processes that occur in the WWTP.
Many commercially available organic compounds, such as methanol or acetic acid, can serve effectively as a carbon source for a BNR process. However, the use of such external carbon sources results in an increase of the operational costs and the sludge production. However, municipal wastewater is a potential source of readily biodegradable organic matter.

One of the possible sources of readily biodegradable organic matter is the PS fermentation. PS contains high concentrations of easily biodegradable organic polymers: proteins and carbohydrates.

Sludge fermentation produce readily biodegradable organic matter. The microorganisms break down biodegradable material in the absence of oxygen.

There are three biological and chemical stages of sludge fermentation: hydrolysis, acidogenesis, and acetogenesis. In most cases, the sludge is made up of large organic polymers. The BNR processes improve when these chains are broken down into their smaller constituent parts. Heterotrophic bacteria access easier to the organic matter of the fermented sludge. 
TABLE 1: Requirements for discharges from urban waste water treatment plants to sensitive areas which are subject to eutrophication. Council directive of 21 May 1991 concerning urban waste water treatment (91/271/EEC).

\begin{tabular}{|c|c|c|c|}
\hline Parameters & Concentration & $\begin{array}{c}\text { Minimun percentage } \\
\text { of reduction }\end{array}$ & $\begin{array}{l}\text { Reference method } \\
\text { of measurement }\end{array}$ \\
\hline Total phosphorus & $\begin{array}{c}2 \mathrm{mg} / \mathrm{L}(10,000-100,000 \text { p.e. }) \\
1 \mathrm{mg} / \mathrm{L} \text { (more than } 100,000 \\
\text { p.e.) }\end{array}$ & 80 & $\begin{array}{l}\text { Molecular } \\
\text { absorption } \\
\text { spectrophotometry }\end{array}$ \\
\hline Total nitrogen & $\begin{array}{c}15 \mathrm{mg} / \mathrm{L} \text { (10,000-100,000 p.e.) } \\
10 \mathrm{mg} / \mathrm{L} \text { (more than } 100,000 \\
\text { p.e.) }\end{array}$ & $70-80$ & $\begin{array}{l}\text { Molecular } \\
\text { absorption } \\
\text { spectrophotometry }\end{array}$ \\
\hline
\end{tabular}

The process of breaking these chains and dissolving the smaller molecules into solution is called hydrolysis. Therefore, hydrolysis of these high-molecular-weight polymeric components is the necessary first step in sludge fermentation. Through hydrolysis the complex organic molecules (carbohydrates, fats, and proteins) are broken down into simple sugars, fatty acids, and aminoacids.

The biological process of acidogenesis results in further breakdown of the remaining components by acidogenic bacteria. Here, volatile fatty acids (VFA) are created, along with ammonia, carbon dioxide, and hydrogen sulfide, as well as other byproducts.

The third stage of sludge fermentation is acetogenesis. Here, simple molecules created through the acidogenesis phase are further digested by acetogens to produce acetic acid, as well as carbon dioxide and hydrogen.

After this processes, in anaerobic conditions, the methanogenesis begins. This process is part of the anaerobic digestion and not of sludge fermentation.

The acidogenesis is characterized by a decrease of $\mathrm{pH}$ in the system, whereas the acetogenesis and the methanogenesis are characterized by an increase of alkalinity in the process.

The other substrate available for readily biodegradable organic matter production within a WWTP is the waste activated sludge (WAS) generated from soluble organic matter removal. WAS contains mostly bacterial mass, and cell lysis is therefore the rate limiting step to obtain readily biodegradable organic matter [1]. WAS contains an inert chemical oxygen demand (COD) greater than PS. Inert COD on WAS depends on the type of biological wastewater treatment.

Several investigations have reported that it can be feasible to produce more readily biodegradable organic matter using PS as fermentation substrate.

Arnai et al. [2] had drawn a conclusion that the VSSs (volatile suspended solids) in PS were more biodegradable than in activated sludge (87\% versus $43 \%)$. Ucisik and Henze [3] obtained a ratio of SCOD to total COD in batch reactors operated for 5 days at $20^{\circ} \mathrm{C}$ for activated sludge significantly lower than those obtained for PS in Avedøre and Lundtofte WWTPs. Yuan et al. [4] also obtained that PS fermentation generated a significantly higher amount of SCOD than WAS. Relatively high nutrient release was observed during WAS fermentation. Therefore, this research analyzes the generation of SCOD on PS fermentation.
Miron et al. [5] reported that the hydrolysis of lipids and carbohydrates of PS increased with SRT. Ahn and Speece [6] obtained that the hydrolysis of COD had an asymptotic tendency, where most of the elutriated SCOD (78-84\%) was produced within the initial 5 days of PS fermentation. However, many research workers have observed that SCOD began to decrease for high retention times (5-6 days) on PS fermentation $[7,8]$ and WAS fermentation $[9,10]$, due to beginning of methanogenesis. This paper compares the fermentation of PS for several SRT.

One solution to increase SRT is to increase sludge concentration in the fermenter. However, SCOD production decreases with the increase of PS concentration [11-13]. One explanation for this behaviour could be that low biomass concentration creates better mixing conditions in the reactor, which results in the improvement of the cell availability to the hydrolysis [11]. Another reason could be that less of the inhibiting compounds, such as zinc or copper, are released into the system during fermentation when a lower biomass concentration is in the feed [14].

On the other hand, Cokgor et al. [15] showed that the level of VSS in PS is also important as an index of biodegradable substrate for hydrolysis. The rate of the reaction is proportional to initial available biodegradable substrate. Higher SCOD generation was observed at higher initial VSS concentration.

This paper analyzes the fermentation of PS for several concentrations.

Increasing the volume of the fermenter and/or sludge concentration is necessary to increase SRT. An interesting alternative is heating and stirring the sludge during fermentation.

Increasing temperature improves PS hydrolysis and acidification [6, 11, 15-17]. Zhang et al. [18] observed the same results on activated sludge fermentation. Hydrolysis and acidification improvement with increasing temperature had an asymptotic trend.

Mahmoud et al. [19] reported that temperature had a significant influence on the hydrolysis of proteins, carbohydrates, and lipids in PS; hydrolysis was significantly higher at $35^{\circ} \mathrm{C}$ than at $25^{\circ} \mathrm{C}$. In addition, a higher rate of hydrolysis was observed at $55^{\circ} \mathrm{C}$, compared with that at $20^{\circ} \mathrm{C}$ and $35^{\circ} \mathrm{C}$ on PS fermentation [6].

The aim of this research was to determine the influence of temperature, agitation, sludge concentration, and SRT to 
obtain readily biodegradable organic matter on PS fermentation. Biodegradable organic matter produced could be used as a substrate in a BNR process: nitrogen and/or phosphorus.

\section{Methods}

2.1. Bench-Scale Experiments. PS used in this study was obtained from the primary settler of two different municipal WWTPs located in Madrid, Spain. PS concentration was different in each WWTP.

Bench-scale experiments of PS fermentation were performed with batch reactors. The batch experiments were conducted by using eight identical reactors with a volume of 0.25 l each one. The reactors were closed with gas-dense blue caps in order to maintain anaerobic conditions.

SCOD produced was measured to compare the relative production of biodegradable organic matter.

Filtration methods, such as $0.45-\mu \mathrm{m}$ filter, are used to determinate the SCOD. The SCOD contains soluble readily biodegradable COD (rbCOD), colloidal COD, and nonbiodegradable soluble COD (nbsCOD). The rbCOD consists of complex SCOD that can be fermented to VFAs [20].

As it is known, the rbCOD concentration has a significant effect on the denitrification rate in preanoxic zones in BNR process, where it will be consumed before the aeration zone. The greater the amount of rbCOD, the faster will be the nitrate reduction rate. For biological phosphorus removal, the rbCOD can be quickly converted to acetate via fermentation in the anaerobic zone for uptake by the phosphorus-storing bacteria [20].

Half of the reactors were operated at a SRT of 1 day and the other half at a SRT of 3 days.

Sludge agitation was assessed using two different fermenter typologies: completely mixed fermenter and static fermenter. Magnetic induction stirrers were used to reproduce completely mixed fermenter conditions in the reactors.

Influence of temperature on PS fermentation was evaluated. Half of the reactors remained at room temperature, while the other half of the reactors were operated at $30^{\circ} \mathrm{C}$.

$30^{\circ} \mathrm{C}$ was considered to be a feasible temperature to achieve in a WWTP using the heat energy obtained from the biogas generated by anaerobic digestion.

A further rise in PS temperature produced a marked increase in SCOD production. Although, energy requirements are higher and maybe biogas produced in the WWTP is not enough to heat PS and WAS before fermentation and anaerobic digestion.

Thermal bath was used on heated static fermenters and hot plates were used on heated completely mixed fermenters.

The eight reactors were operated in the conditions shown in Tables 2 and 3. Experiments were repeated three times for each WWTP.

No regulation on $\mathrm{pH}$ was applied. SCOD $(\mathrm{mg} / \mathrm{L}), \mathrm{pH}$, TSS $(\mathrm{g} / \mathrm{L})$, and VSS $(\mathrm{g} / \mathrm{L})$ were measured in raw sludge and in all the experiments. Total COD $(\mathrm{mg} / \mathrm{L})$ was measured only in raw sludge. Total COD was considered to be the same in all the fermented reactors with the same raw sludge.
2.2. Analytical Methods. The analyses of COD, SCOD, TSS, and VSS were conducted in accordance with APHA Standard Methods (2005).

\section{Results and Discussion}

The experiments results are shown in Tables 2 and 3. Setting the temperature to $30^{\circ} \mathrm{C}$ was not possible in some of the heated and stirred samples. The real temperature was between $30^{\circ} \mathrm{C}$ and $35^{\circ} \mathrm{C}$.

The SCOD yield is a measure for the degree of success of fermentation. The SCOD yield is the amount of SCOD to total COD. The SCOD yields of the batch studies performed with PS are shown in Figures 1 and 2. Figure 1 shows the percentage of SCOD to total COD in each experiment. Figure 2 shows the SCOD yield average for each plant and the SCOD yield total average.

Specific SCOD production was expressed by g/L of SCOD in the hydrolysate per unit g VSS/L (i.e., g SCOD/g VSS) in the feed to avoid any influence of the inorganic matter fraction in the sludge on the results. VSS content of the sludge is generally considered to be the organic part. The specific SCOD productions are represented in Figures 3 and 4. Figure 3 shows the specific SCOD production in each experiment. Figure 4 shows the average of the specific SCOD production for each plant and the specific SCOD production total average.

As expected, a higher SCOD concentration was obtained in the experiments from WWTP 1 because the raw sludge was more concentrated than in WWTP 2. Raw sludge from WWPT 1 had a longer retention time in the primary settling tanks. The fermentation process was expected to be more advanced in the raw sludge from WWTP 1 than in the raw sludge from WWTP 2. However, the ratios of SCOD (g)/STv (g) obtained for both plants are very similar. These results imply that the PS concentration did not affect the fermentation.

According to Yuan et al. [13], Skalsky and Daigger [11], and Banister and Pretorius [12], a decrease in sludge concentration favored hydrolysis. On the other hand, Cokgor et al. [15] obtained an increase in SCOD generation when sludge concentration also increased.

However, in this study the PS concentration did not influence SCOD production during fermentation.

Based on the results obtained, a completely mixed fermenter and a sludge thickener-fermenter configurations are more interesting than an activated primary tank. A smaller fermenter volume is needed if a more concentrated sludge is fermented. In addition, SRT would be higher in a fermenter existing if sludge concentration is increased. Any possible leakage of solids in the primary clarifier and excess acidified water to be treated are avoided in a completely mixed fermenter or in a sludge thickener-fermenter configuration. Proper thickener-fermenter design is important to prevent overloading and suspended solids escaping in the overflow.

SCOD yield in heated and stirred samples with 3 days of SRT was similar for both WWTP. Only small differences were observed, probably due to the higher temperature of the 
TABLE 2: Influence of temperature, agitation, sludge concentration, and SRT on PS from WWTP 1 fermentation: SCOD yield and specific SCOD production.

\begin{tabular}{|c|c|c|c|c|c|c|c|c|c|c|}
\hline Sample & $\begin{array}{l}\text { SRT } \\
\text { (days) }\end{array}$ & $\begin{array}{l}\text { Fermenter } \\
\text { typology }\end{array}$ & Temperature & $\mathrm{pH}$ & TSS $(\mathrm{g} / \mathrm{L})$ & VSS/TSS & $\begin{array}{l}\text { COD } \\
(\mathrm{mg} / \mathrm{L})\end{array}$ & $\begin{array}{l}\text { SCOD } \\
(\mathrm{mg} / \mathrm{L})\end{array}$ & $\begin{array}{c}\text { SCOD } \\
(\mathrm{mg} / \mathrm{L}) \\
/ \mathrm{COD} \\
(\mathrm{mg} / \mathrm{L})\end{array}$ & $\begin{array}{l}\operatorname{SCOD}(\mathrm{g}) / \\
\operatorname{VSS}(\mathrm{g})\end{array}$ \\
\hline \multirow{9}{*}{ Sample 1} & \multicolumn{3}{|c|}{ Raw sludge } & 6.26 & 28.70 & $69 \%$ & 30856 & 658 & $2 \%$ & 0.03 \\
\hline & \multirow{3}{*}{1} & \multirow{2}{*}{$\begin{array}{l}\text { Static } \\
\text { fermenter }\end{array}$} & $\begin{array}{c}\text { Room } \\
\text { temperature }\end{array}$ & 5.87 & 24.68 & $66 \%$ & 30856 & 1242 & $4 \%$ & 0.08 \\
\hline & & & $30^{\circ} \mathrm{C}$ & 5.47 & 32.65 & $66 \%$ & 30856 & 1602 & $5 \%$ & 0.07 \\
\hline & & \multirow{2}{*}{$\begin{array}{l}\text { Completely } \\
\text { mixed } \\
\text { fermenter }\end{array}$} & $\begin{array}{c}\text { Room } \\
\text { temperature }\end{array}$ & 6.16 & 28.07 & $67 \%$ & 30856 & 1889 & $6 \%$ & 0.10 \\
\hline & & & $30^{\circ} \mathrm{C}$ & 6.42 & 30.81 & $66 \%$ & 30856 & 3099 & $10 \%$ & 0.15 \\
\hline & \multirow{4}{*}{3} & \multirow{2}{*}{$\begin{array}{l}\text { Static } \\
\text { fermenter }\end{array}$} & $\begin{array}{c}\text { Room } \\
\text { temperature }\end{array}$ & 5.48 & 26.84 & $65 \%$ & 30856 & 2676 & $9 \%$ & 0.15 \\
\hline & & & $30^{\circ} \mathrm{C}$ & 5.20 & 29.06 & $64 \%$ & 30856 & 3444 & $11 \%$ & 0.18 \\
\hline & & \multirow{2}{*}{$\begin{array}{l}\text { Completely } \\
\text { mixed } \\
\text { fermenter }\end{array}$} & $\begin{array}{c}\text { Room } \\
\text { temperature }\end{array}$ & 5.60 & 28.26 & $65 \%$ & 30856 & 2340 & $8 \%$ & 0.13 \\
\hline & & & $30^{\circ} \mathrm{C}$ & 7.16 & 37.16 & $65 \%$ & 30856 & 4311 & $14 \%$ & 0.18 \\
\hline \multirow{9}{*}{ Sample 2} & \multirow{4}{*}{1} & \multicolumn{2}{|c|}{ Raw sludge } & 5.84 & 33.88 & $65 \%$ & 36298 & 1139 & $3 \%$ & 0.05 \\
\hline & & \multirow[t]{2}{*}{$\begin{array}{l}\text { Static } \\
\text { fermenter }\end{array}$} & $\begin{array}{c}\text { Room } \\
\text { temperature }\end{array}$ & 5.11 & 32.85 & $65 \%$ & 36298 & 1806 & $5 \%$ & 0.08 \\
\hline & & & $30^{\circ} \mathrm{C}$ & 4.97 & 32.78 & $65 \%$ & 36298 & 2336 & $6 \%$ & 0.11 \\
\hline & & \multirow{2}{*}{$\begin{array}{l}\text { Completely } \\
\text { mixed } \\
\text { fermenter }\end{array}$} & $\begin{array}{c}\text { Room } \\
\text { temperature }\end{array}$ & 5.25 & 31.76 & $68 \%$ & 36298 & 2492 & $7 \%$ & 0.11 \\
\hline & & & $30^{\circ} \mathrm{C}$ & 5.60 & 34.34 & $64 \%$ & 36298 & 3602 & $10 \%$ & 0.16 \\
\hline & \multirow{4}{*}{3} & \multirow[t]{2}{*}{$\begin{array}{l}\text { Static } \\
\text { fermenter }\end{array}$} & $\begin{array}{c}\text { Room } \\
\text { temperature }\end{array}$ & 5.13 & 36.91 & $65 \%$ & 36298 & 2403 & $7 \%$ & 0.10 \\
\hline & & & $30^{\circ} \mathrm{C}$ & 4.83 & 32.74 & $64 \%$ & 36298 & 3276 & $9 \%$ & 0.16 \\
\hline & & \multirow{2}{*}{$\begin{array}{l}\text { Completely } \\
\text { mixed } \\
\text { fermenter }\end{array}$} & $\begin{array}{c}\text { Room } \\
\text { temperature }\end{array}$ & 5.10 & 33.96 & $64 \%$ & 36298 & 3588 & $10 \%$ & 0.17 \\
\hline & & & $30^{\circ} \mathrm{C}$ & 5.75 & 33.02 & $62 \%$ & 36298 & 5043 & $14 \%$ & 0.25 \\
\hline \multirow{9}{*}{ Sample 3} & \multirow{4}{*}{1} & \multicolumn{2}{|c|}{ Raw sludge } & 6.03 & 29.60 & $66 \%$ & 32758 & 1052 & $3 \%$ & 0.05 \\
\hline & & \multirow[t]{2}{*}{$\begin{array}{l}\text { Static } \\
\text { fermenter }\end{array}$} & $\begin{array}{c}\text { Room } \\
\text { temperature }\end{array}$ & 5.30 & 27.68 & $66 \%$ & 32758 & 1545 & $5 \%$ & 0.09 \\
\hline & & & $30^{\circ} \mathrm{C}$ & 5.18 & 28.25 & $65 \%$ & 32758 & 2379 & $7 \%$ & 0.13 \\
\hline & & $\begin{array}{l}\text { Completely } \\
\text { mixed }\end{array}$ & $\begin{array}{c}\text { Room } \\
\text { temperature }\end{array}$ & 5.35 & 28.23 & $67 \%$ & 32758 & 1863 & $6 \%$ & 0.10 \\
\hline & & fermenter & $30^{\circ} \mathrm{C}$ & 6.43 & 29.39 & $66 \%$ & 32758 & 2871 & $9 \%$ & 0.15 \\
\hline & \multirow{4}{*}{3} & \multirow[t]{2}{*}{$\begin{array}{l}\text { Static } \\
\text { fermenter }\end{array}$} & $\begin{array}{c}\text { Room } \\
\text { temperature }\end{array}$ & 5.14 & 31.77 & $66 \%$ & 32758 & 2421 & $7 \%$ & 0.12 \\
\hline & & & $30^{\circ} \mathrm{C}$ & 5.02 & 28.36 & $65 \%$ & 32758 & 2955 & $9 \%$ & 0.16 \\
\hline & & \multirow{2}{*}{$\begin{array}{l}\text { Completely } \\
\text { mixed } \\
\text { fermenter }\end{array}$} & $\begin{array}{c}\text { Room } \\
\text { temperature }\end{array}$ & 5.56 & 31.38 & $65 \%$ & 32758 & 3330 & $10 \%$ & 0.16 \\
\hline & & & $30^{\circ} \mathrm{C}$ & 6.08 & 34.29 & $63 \%$ & 32758 & 4030 & $12 \%$ & 0.19 \\
\hline
\end{tabular}

samples from WWTP 1 because of the difficulty to control the temperature.

Stirring, heating, and high SRT increased SCOD production (Figures 1, 2, 3, and 4). The influence of each operational parameter can be seen clearly.

Heating the sludge to $30^{\circ} \mathrm{C}$ without stirring it or stirring the sludge at room temperature had a similar effect on SCOD yield as shown on average results in Figure 2.
Stirring or heating the reactor with a day of SRT had a SCOD production similar to that of a static fermenter with three days of SRT. Therefore, only a third of the fermenter volume would be necessary if the sludge is stirred or heated during the fermentation. These statements remained valid by comparing the samples with three days of SRT.

SCOD production would be higher if the sludge is stirred and heated. Volume fermenter could be further reduced 
TABLE 3: Influence of temperature, agitation, sludge concentration, and SRT on PS from WWTP 2 fermentation: SCOD yield and specific SCOD production.

\begin{tabular}{|c|c|c|c|c|c|c|c|c|c|c|}
\hline Sample & $\begin{array}{l}\text { SRT } \\
\text { (days) }\end{array}$ & $\begin{array}{l}\text { Fermenter } \\
\text { typology }\end{array}$ & Temperature & $\mathrm{pH}$ & TSS (g/L) & VSS/TSS & $\begin{array}{c}\mathrm{COD} \\
(\mathrm{mg} / \mathrm{L})\end{array}$ & $\begin{array}{l}\text { SCOD } \\
(\mathrm{mg} / \mathrm{L})\end{array}$ & $\begin{array}{c}\text { SCOD } \\
(\mathrm{mg} / \mathrm{L}) \\
/ \mathrm{COD} \\
(\mathrm{mg} / \mathrm{L})\end{array}$ & $\begin{array}{l}\operatorname{SCOD}(\mathrm{g}) / \\
\operatorname{VSS}(\mathrm{g})\end{array}$ \\
\hline \multirow{9}{*}{ Sample 4} & \multicolumn{3}{|c|}{ Raw sludge } & 7.35 & 4.46 & $77 \%$ & 4863 & 312 & $6 \%$ & 0.09 \\
\hline & \multirow{3}{*}{1} & \multirow{2}{*}{$\begin{array}{l}\text { Static } \\
\text { fermenter }\end{array}$} & $\begin{array}{c}\text { Room } \\
\text { temperature }\end{array}$ & 7.13 & 3.92 & $75 \%$ & 4863 & 334 & $7 \%$ & 0.11 \\
\hline & & & $30^{\circ} \mathrm{C}$ & 6.57 & 3.99 & $75 \%$ & 4863 & 508 & $10 \%$ & 0.17 \\
\hline & & \multirow{2}{*}{$\begin{array}{l}\text { Completely } \\
\text { mixed } \\
\text { fermenter }\end{array}$} & $\begin{array}{c}\text { Room } \\
\text { temperature }\end{array}$ & 7.78 & 4.76 & $73 \%$ & 4863 & 345 & $7 \%$ & 0.10 \\
\hline & & & $30^{\circ} \mathrm{C}$ & 7.06 & 4.23 & $76 \%$ & 4863 & 482 & $10 \%$ & 0.15 \\
\hline & \multirow{4}{*}{3} & \multirow{2}{*}{$\begin{array}{l}\text { Static } \\
\text { fermenter }\end{array}$} & $\begin{array}{c}\text { Room } \\
\text { temperature }\end{array}$ & 6.81 & 3.75 & $72 \%$ & 4863 & 401 & $8 \%$ & 0.15 \\
\hline & & & $30^{\circ} \mathrm{C}$ & 6.98 & 4.20 & $70 \%$ & 4863 & 462 & $10 \%$ & 0.16 \\
\hline & & \multirow{2}{*}{$\begin{array}{l}\text { Completely } \\
\text { mixed } \\
\text { fermenter }\end{array}$} & $\begin{array}{c}\text { Room } \\
\text { temperature }\end{array}$ & 7.97 & 4.13 & $74 \%$ & 4863 & 423 & $9 \%$ & 0.14 \\
\hline & & & $30^{\circ} \mathrm{C}$ & 8.18 & 4.61 & $73 \%$ & 4863 & 543 & $11 \%$ & 0.16 \\
\hline \multirow{9}{*}{ Sample 5} & \multirow{4}{*}{1} & \multicolumn{2}{|c|}{ Raw sludge } & 7.48 & 2.99 & $73 \%$ & 2677 & 125 & $5 \%$ & 0.06 \\
\hline & & \multirow{2}{*}{$\begin{array}{l}\text { Static } \\
\text { fermenter }\end{array}$} & $\begin{array}{c}\text { Room } \\
\text { temperature }\end{array}$ & 7.14 & 3.20 & $74 \%$ & 2677 & 204 & $8 \%$ & 0.09 \\
\hline & & & $30^{\circ} \mathrm{C}$ & 6.79 & 2.33 & $70 \%$ & 2677 & 207 & $8 \%$ & 0.13 \\
\hline & & \multirow{2}{*}{$\begin{array}{l}\text { Completely } \\
\text { mixed } \\
\text { fermenter }\end{array}$} & $\begin{array}{l}\text { Room } \\
\text { temperature }\end{array}$ & 6.62 & 2.95 & $72 \%$ & 2677 & 129 & $5 \%$ & 0.06 \\
\hline & & & $30^{\circ} \mathrm{C}$ & 6.64 & 2.63 & $73 \%$ & 2677 & 157 & $6 \%$ & 0.08 \\
\hline & \multirow{4}{*}{3} & \multirow[t]{2}{*}{$\begin{array}{l}\text { Static } \\
\text { fermenter }\end{array}$} & $\begin{array}{l}\text { Room } \\
\text { temperature }\end{array}$ & 6.61 & 3.16 & $72 \%$ & 2677 & 168 & $6 \%$ & 0.07 \\
\hline & & & $30^{\circ} \mathrm{C}$ & 6.50 & 1.94 & $66 \%$ & 2677 & 190 & $7 \%$ & 0.15 \\
\hline & & \multirow{2}{*}{$\begin{array}{l}\text { Completely } \\
\text { mixed } \\
\text { fermenter }\end{array}$} & $\begin{array}{l}\text { Room } \\
\text { temperature }\end{array}$ & 6.51 & 2.55 & $69 \%$ & 2677 & 238 & $9 \%$ & 0.14 \\
\hline & & & $30^{\circ} \mathrm{C}$ & 6.44 & 2.67 & $68 \%$ & 2677 & 278 & $10 \%$ & 0.15 \\
\hline \multirow{9}{*}{ Sample 6} & \multirow{4}{*}{1} & \multicolumn{2}{|c|}{ Raw sludge } & 7.41 & 5.26 & $73 \%$ & 5621 & 247 & $4 \%$ & 0.06 \\
\hline & & \multirow{2}{*}{$\begin{array}{l}\text { Static } \\
\text { fermenter }\end{array}$} & $\begin{array}{c}\text { Room } \\
\text { temperature }\end{array}$ & 6.88 & 4.60 & $75 \%$ & 5621 & 383 & $7 \%$ & 0.11 \\
\hline & & & $30^{\circ} \mathrm{C}$ & 6.53 & 4.28 & $74 \%$ & 5621 & 547 & $10 \%$ & 0.17 \\
\hline & & $\begin{array}{l}\text { Completely } \\
\text { mixed }\end{array}$ & $\begin{array}{l}\text { Room } \\
\text { temperature }\end{array}$ & 6.74 & 4.66 & $75 \%$ & 5621 & 526 & $9 \%$ & 0.15 \\
\hline & \multirow{5}{*}{3} & fermenter & $30^{\circ} \mathrm{C}$ & 6.79 & 4.86 & $74 \%$ & 5621 & 630 & $11 \%$ & 0.18 \\
\hline & & \multirow[t]{2}{*}{$\begin{array}{l}\text { Static } \\
\text { fermenter }\end{array}$} & $\begin{array}{l}\text { Room } \\
\text { temperature }\end{array}$ & 6.55 & 4.66 & $75 \%$ & 5621 & 575 & $10 \%$ & 0.16 \\
\hline & & & $30^{\circ} \mathrm{C}$ & 6.78 & 4.07 & $74 \%$ & 5621 & 697 & $12 \%$ & 0.23 \\
\hline & & \multirow{2}{*}{$\begin{array}{l}\text { Completely } \\
\text { mixed } \\
\text { fermenter }\end{array}$} & $\begin{array}{l}\text { Room } \\
\text { temperature }\end{array}$ & 6.37 & 3.91 & $75 \%$ & 5621 & 679 & $12 \%$ & 0.23 \\
\hline & & & $30^{\circ} \mathrm{C}$ & 7.14 & 4.36 & $74 \%$ & 5621 & 653 & $12 \%$ & 0.20 \\
\hline
\end{tabular}

to obtain the same amount of SCOD. In fact, the reactors agitated and heated with a SRT of one day and the reactors heated or agitated for three days produced a similar amount of SCOD.

According to the results obtained, PS fermented in a completely mixed fermenter heated to a temperature between $30^{\circ} \mathrm{C}$ and $35^{\circ} \mathrm{C}$ and with a SRT of 3 days will be the best choice to improve the BNR processes.
In WWTP with anaerobic digestion, methanogens used PS to produce methane. If PS is fermented to feed heterotrophic bacteria in BNR process, the biogas production is reduced to improve BNR.

SCOD in the overflow was measured in six of the static fermenters. Overflow SCOD was between $90 \%$ and $92 \%$ of the sludge total SCOD in four of them and $62 \%$ and $70 \%$ in the other two samples. Therefore, an excellent performance in the elutriation was obtained in static samples. 


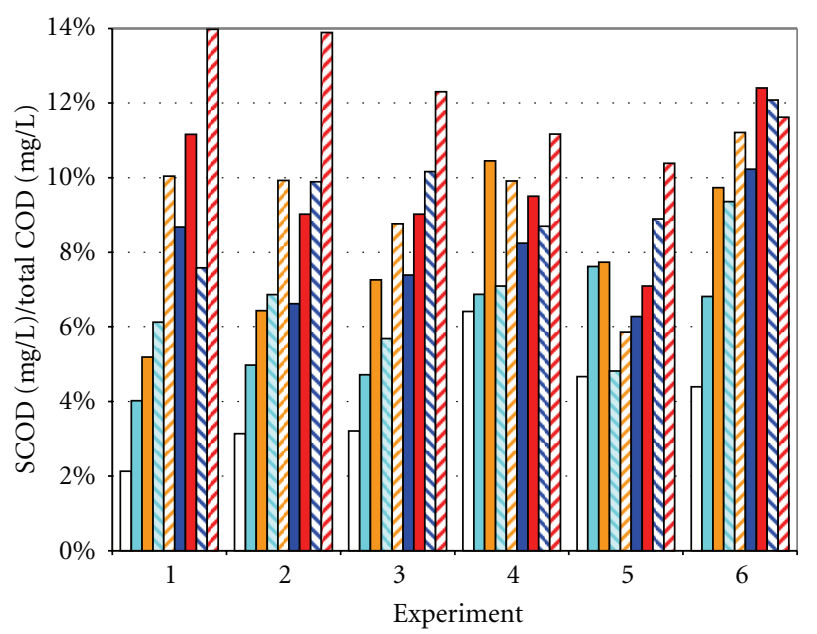
$\square$ Raw sludge
$\square$ Static fermenter room temperature 1 day SRT
$\checkmark$ Static fermenter $30^{\circ} \mathrm{C} 1$ day SRT
$\square$ Completely mixed fermenter room temperature 1 day SRT
$\square$ Completely mixed fermenter $30^{\circ} \mathrm{C} 1$ day SRT

Static fermenter room temperature 3 days SRT

Static fermenter $30^{\circ} \mathrm{C} 3$ days SRT

N Completely mixed fermenter room temperature 3 days SRT

$\square$ Completely mixed fermenter $30^{\circ} \mathrm{C} 3$ days SRT

FIGURE 1: SCOD yield for each experiment.

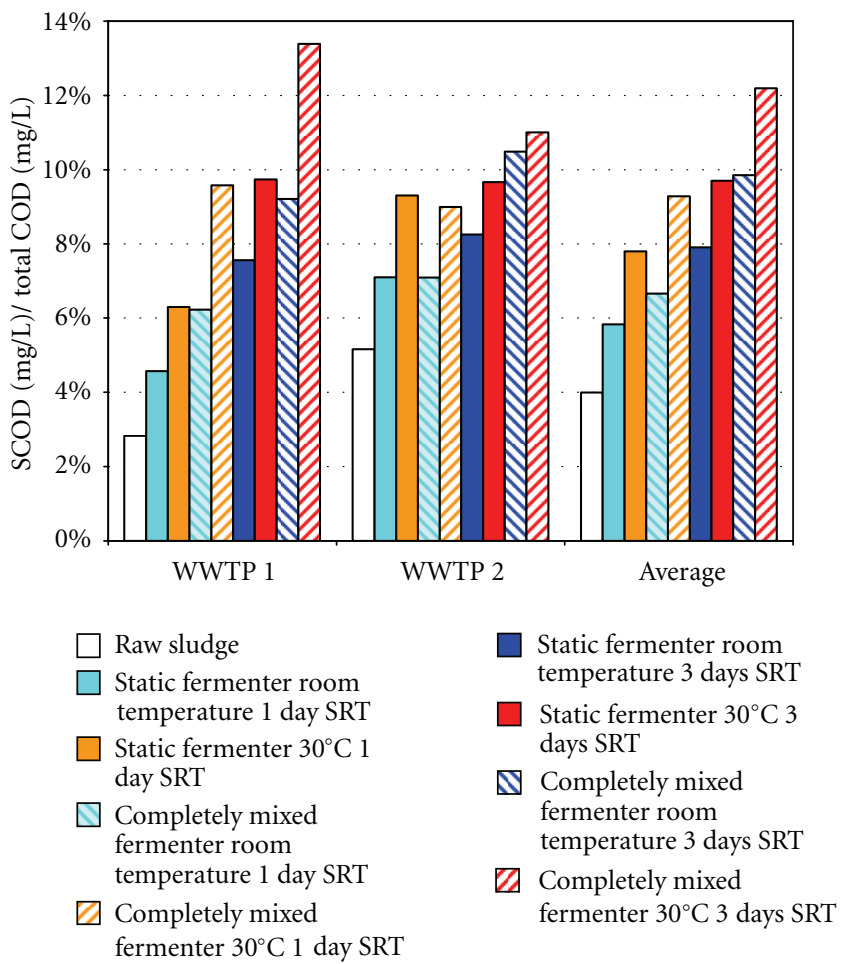

FIGURE 2: SCOD yield for WWTP 1, WWTP 2, and SCOD yield total average. 
The advantage of using the overflow of a static fermenter is that it has low particulate slowly biodegradable COD. However, the amount of SCOD is lower than in the fermented PS from a completely mixed reactor.

The $\mathrm{pH}$ has increased in some completely mixed and heated reactors, especially in those fermented for 3 days, compared to raw sludge and reactors with low SRT. An increase in $\mathrm{pH}$ may indicate that the acetogenesis and, maybe, the methanogenesis have started.

\section{Conclusions}

The influence of temperature, agitation, sludge concentration, and SRT on PS fermentation was evaluated. SCOD produced was measured to assess the degree of hydrolysis achieved.

Increasing temperature to $30^{\circ} \mathrm{C}$, increasing SRT from 1 to 3 days, or stirring the sludge during fermentation produced a greater amount of SCOD. PS concentration did not affect the SCOD production.

Increasing temperature to $30^{\circ} \mathrm{C}$, increasing SRT from 1 to 3 days, or choosing a completely mixed typology for the fermenter rather than a static fermenter had a similar effect on the SCOD production. The influence of each operational parameter on PS hydrolysis was observed clearly. The highest SCOD yield was obtained when the reactors were heated and stirred for 3 days.

Heating and stirring the sludge are good solutions in WWTP with high sludge production, where the construction of a fermenter with a high SRT is complicated by the lack of space. Heating the sludge would be possible by combustion of biogas produced on anaerobic digestion. Stirring the sludge is a simple process with a low energy cost and easy implementation. The SCOD produced would be higher, while the investment would be lower.

\section{References}

[1] I. S. Turoviskiy and P. K. Mathai, Wastewater Sludge Processing, chapter 2, John Wiley \& Sons, Hoboken, NJ, USA, 2006.

[2] C. Arnaiz, J. C. Gutierrez, and J. Lebrato, "Biomass stabilization in the anaerobic digestion of wastewater sludges," Bioresource Technology, vol. 97, no. 10, pp. 1179-1184, 2006.

[3] A. S. Ucisik and M. Henze, "Biological hydrolysis and acidification of sludge under anaerobic conditions: the effect of sludge type and origin on the production and composition of volatile fatty acids," Water Research, vol. 42, no. 14, pp. 3729-3738, 2008.

[4] Q. Yuan, M. Baranowski, and J. A. Oleszkiewicz, "Effect of sludge type on the fermentation products," Chemosphere, vol. 80, no. 4, pp. 445-449, 2010.

[5] Y. Miron, G. Zeeman, J. B. Van Lier, and G. Lettinga, "The role of sludge retention time in the hydrolysis and acidification of lipids, carbohydrates and proteins during digestion of primary sludge in cstr systems," Water Research, vol. 34, no. 5, pp. 17051713, 2000.

[6] Y. H. Ahn and R. E. Speece, "Elutriated acid fermentation of municipal primary sludge," Water Research, vol. 40, no. 11, pp. 2210-2220, 2006.
[7] E. V. Munch E., J. Keller, P. Lant, and R. Newell, "Mathematical modelling of prefermenters-i. model development and verification," Water Research, vol. 33, no. 12, pp. 2757-2768, 1999.

[8] H. Wu, J. Gao, D. Yang, Q. Zhou, and W. Liu, "Alkaline fermentation of primary sludge for short-chain fatty acids accumulation and mechanism," Chemical Engineering Journal, vol. 160, no. 1, pp. 1-7, 2010.

[9] Y. Chen, A. A. Randall, and T. McCue, "The efficiency of enhanced biological phosphorus removal from real wastewater affected by different ratios of acetic to propionic acid," Water Research, vol. 38, no. 1, pp. 27-36, 2004.

[10] S. Jiang, Y. Chen, Q. Zhou, and G. Gu, "Biological short-chain fatty acids (scfas) production from waste-activated sludge affected by surfactant," Water Research, vol. 41, no. 14, pp. 3112-3120, 2007.

[11] D. S. Skalsky and G. T. Daigger, "Wastewater solids fermentation for volatile acid production and enhanced biological phosphorus removal," Water Environment Research, vol. 67, no. 2, pp. 230-237, 1995.

[12] S. S. Banister and W. A. Pretorius, "Optimisation of primary sludge acidogenic fermentation for biological nutrient removal," Water Sa, vol. 24, no. 1, pp. 35-41, 1998.

[13] Q. Yuan, R. Sparling, and J. A. Oleszkiewicz, "Waste activated sludge fermentation: effect of solids retention time and biomass concentration," Water Research, vol. 43, no. 20, pp. 5180-5186, 2009.

[14] V. P. Utgikar, N. Chaudhary, A. Koeniger, H. H. Tabak, J. R. Haines, and R. Govind, "Toxicity of metals and metal mixtures: analysis of concentration and time dependence for zinc and copper," Water Research, vol. 38, no. 17, pp. 36513658, 2004.

[15] E. U. Cokgor, S. Oktay, D. O. Tas, G. E. Zengin, and D. Orhon, "Influence of $\mathrm{pH}$ and temperature on soluble substrate generation with primary sludge fermentation," Bioresource Technology, vol. 100, no. 1, pp. 380-386, 2009.

[16] I. Maharaj and P. Elefsiniotis, "The role of hrt and low temperature on the acid-phase anaerobic digestion of municipal and industrial wastewaters," Bioresource Technology, vol. 76, no. 3, pp. 191-197, 2001.

[17] N. Ferreiro and M. Soto, "Anaerobic hydrolysis of primary sludge: influence of sludge concentration and temperature," Water Science and Technology, vol. 47, no. 12, pp. 239-246, 2003.

[18] P. Zhang, Y. Chen, T. Y. Huang, and Q. Zhou, "Waste activated sludge hydrolysis and short-chain fatty acids accumulation in the presence of sdbs in semi-continuous flow reactors: effect of solids retention time and temperature," Chemical Engineering Journal, vol. 148, no. 2-3, pp. 348-353, 2009.

[19] N. Mahmoud, G. Zeeman, H. Gijzen, and G. Lettinga, "Anaerobic stabilisation and conversion of biopolymers in primary sludge-effect of temperature and sludge retention time," Water Research, vol. 38, no. 4, pp. 983-991, 2004.

[20] Metcalf \& Eddy, Wastewater Engineering. Treatment and Reuse, McGraw-Hill, 4th. 

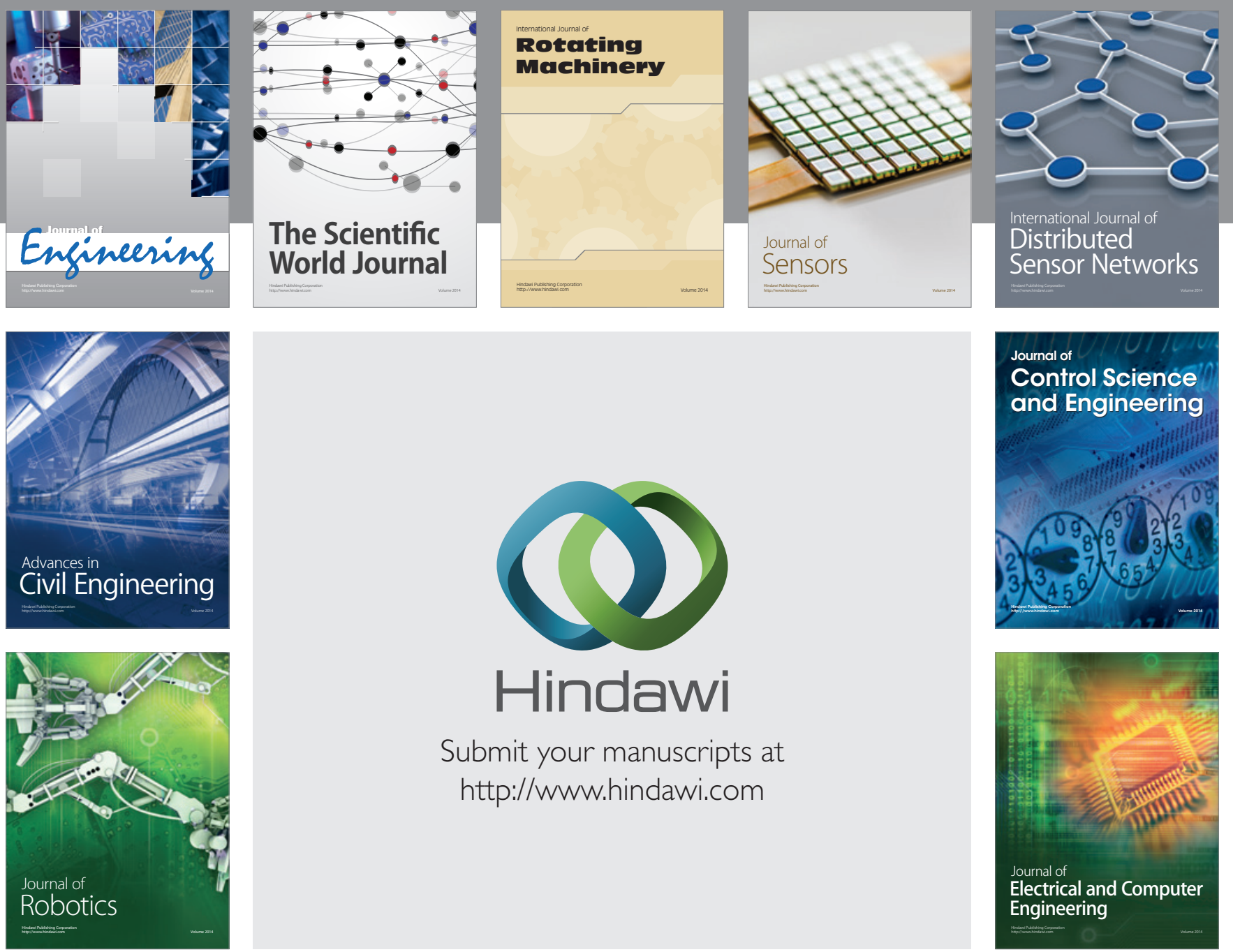

Submit your manuscripts at

http://www.hindawi.com
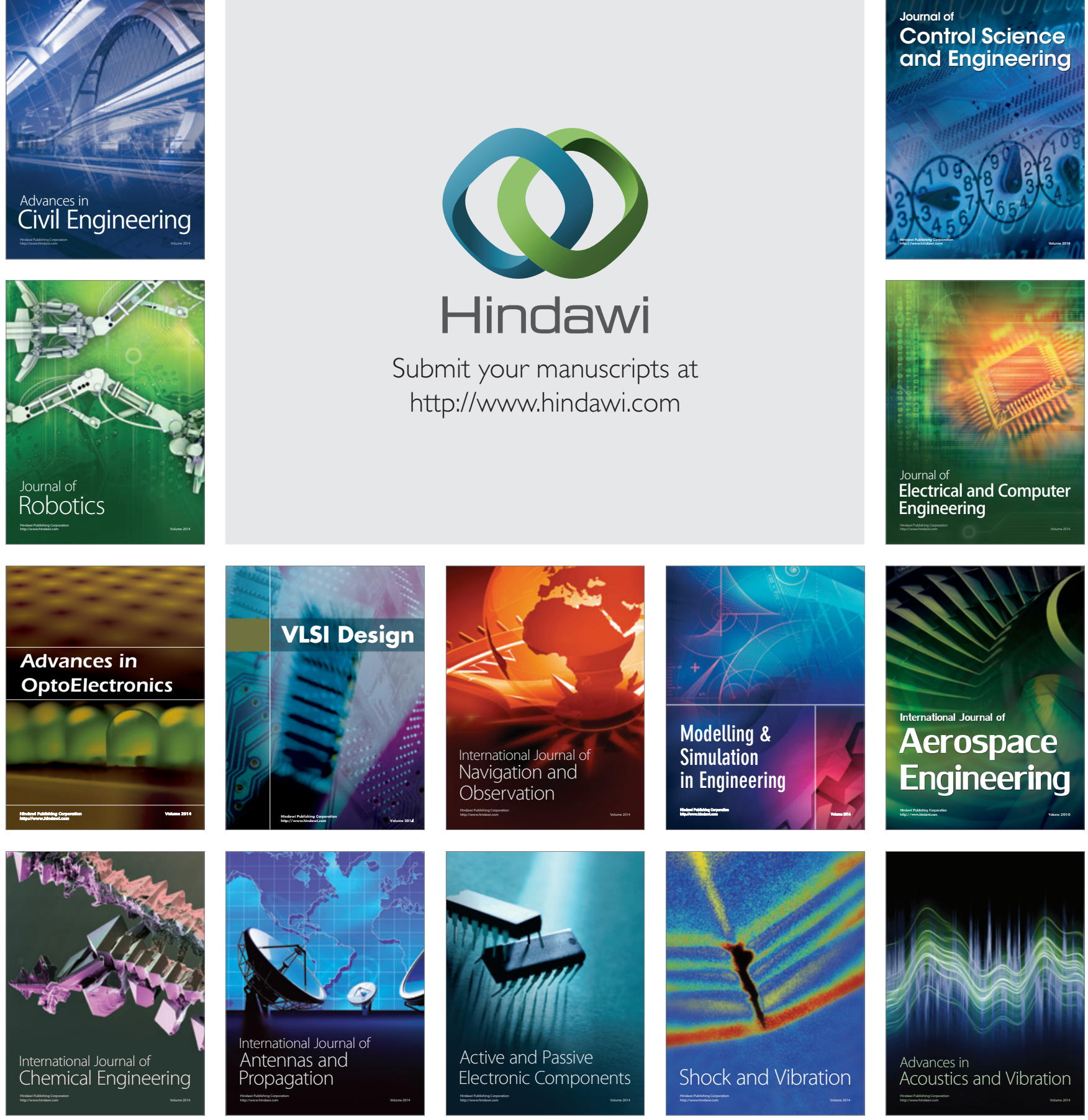